Institute of Chemistry in Karachi, has championed plans to create a multibillion Pan Islamic R\&D Fund by the 57-state Organization of the Islamic Conference (see Nature 416, 120-122;2002).

Perhaps the most contentious suggestion was that science is stifled by a lack of democracy in authoritarian Islamic countries. Adnan Badran, president of the Beirut-based Arab Academy of Sciences and former deputy director-general of the United Nations Educational, Scientific and Cultural Organization, is convinced that a lack of free expression and creative thinking explains the absence of a vibrant scientific culture. "Oppressive regimes are hindering the creativity of scientists in Islamic states, imprisoning the brains of the élite," he said.

Whether religious culture helps or hinders the advancement of Islamic society is a "legitimate question", argued Çigdem Kagitcibasi, a psychologist and member of the Turkish Academy of Sciences. She said it is important to assess the impact of religious dogma on education, and expressed concern about the growth of fundamentalist religious schools.

Such arguments drew fire from Mohamed Falougi, deputy director general of the Islamic Educational, Scientific and Cultural Organization, who said that they are political, and should not arise at a meeting of scientists. Saleh Al-Athel, president of the King Abdulaziz City for Science \& Technology in Riyadh, Saudi Arabia, warned against the idea that science is synonymous with progress, whereas Islam is somehow 'backward'.

Although the academic élite of Islamic countries is generally suspicious of the United States' motives and commitment to democracy in the region, many scientists and intellectuals are now so impatient for greater freedom that they are willing to contemplate change imposed from outside, according to Badran.

The meeting provided a rare opportunity for Western scientific leaders, such as Bruce Alberts, president of the US National Academy of Sciences, to rub shoulders with their Islamic counterparts. Most said that the gathering marked a positive step towards greater cooperation between Islamic and Western scientists.

Rahman added that scientists are well placed to engage in dialogue between Islamic countries and the West. This was echoed by Abdel-Salam Majali, president of the Islamic Academy of Sciences and a former prime minister of Jordan. "Our scientific community needs to work hard at projecting the true image of our Islamic faith, and counter the gross distortions that have become part of Western mentality toward Islam since the events of 9/11," he said.

\title{
Biotech project in turmoil as Michigan balances books
}

Jonathan Knight, San Francisco

A project to turn Michigan into a biotechnology powerhouse is being gutted to help keep the state out of debt.

The Life Sciences Corridor - established in 1999 with settlement money from a multistate lawsuit against the tobacco industry provides nearly $\$ 50$ million a year in research funding to Michigan's major research universities and biotechnology start-ups (see Nature 400, 391; 1999). In the long term, the project is intended to help lessen the state's economic reliance on the motor industry.

But in February, Michigan's governor, Jennifer Granholm, chopped the programme's 2003 budget down to $\$ 32.5$ million as part of a package of cuts to address the state's \$285-million shortfall. The deficit is projected to grow dramatically, and on 6 March Granholm proposed cutting all but \$20 million from the programme in 2004.

Supporters of the project were surprised by the governor's decision. "In terms of creating jobs and sources of revenue, this was a rather creative proposal," says Frank Press, a former president of the National Academy of Sciences and now a consultant with the Washington Advisory Group in Washington DC, which advised on early project planning. "To regress now is short-sighted."

The Life Sciences Corridor was set up as a 20-year project to foster the sort of growth in commercial biotechnology that has surrounded universities in other states, notably California and Massachusetts.

Nearly half of the programme's annual

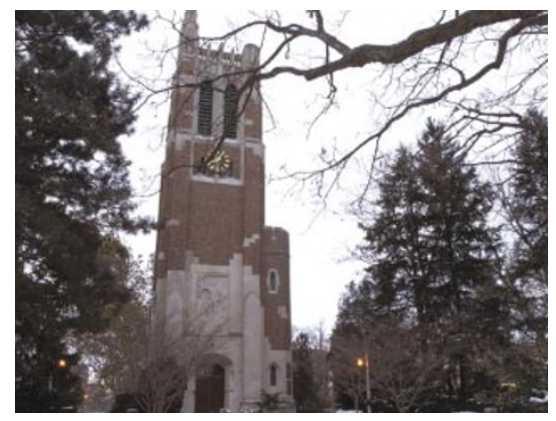

Michigan State University is among the institutions set to lose biotechnology funding.

budget, administered by the Michigan Economic Development Corporation, has gone to fund basic research at public institutions such as Michigan State University, with the rest helping private start-up companies or public-private collaborations.

So far the fund has been involved in some 50 Michigan start-ups. The declining economy has made the project's job even more important, says its managing director, Raili Kerppola. "We have been playing the critical role of providing seed capital to new companies while private-sector investment has pretty much shut down," he says.

Grants from the Life Sciences Corridor are given in lump sums, so previous awards will remain untouched, Kerppola says. But far fewer awards will be made this year.

Granholm said that cuts were a "tough choice" forced by Michigan voters' resistance to tax increases.

\section{Auction of DNA archive cancelled}

\section{Rex Dalton, San Diego}

A historic archive of molecular-biology papers will not be broken up and sold, as planned, at auction next month. Jeremy Norman, the California-based owner of the archive, said that he hopes instead to keep it intact and sell it to a library.

The auction house Christie's announced on 4 March that it was cancelling the auction in New York of the Jeremy Norman Molecular Biology Archive. Including papers from Aaron Klug, Max Perutz, Rosalind Franklin, Francis Crick and James Watson, the archive was valued for Christie's at between $\$ 2.2$ million and $\$ 3.3$ million.

“Christie's is offering my collection en bloc to various institutional libraries in England and the United States," Norman said in a statement. "Several institutions have expressed interest and we are pursuing a private sale."

"I am glad that Christie's has withdrawn the auction," says Klug, who sold his papers to the archive on the basis of an agreement that they would be kept together.

When the proposed sale, scheduled for 25 April, was disclosed last month, Klug and others expressed anger that the papers were to be split up (see Nature 421, 564; 2003).

Al Seckel, a neuroscientist at the California Institute of Technology in Pasadena who purchased the papers for Norman, said that the auction was cancelled after his extensive documentation prohibiting breaking up the archive was brought to the attention of Christie's. Neither Christie's nor Norman would comment on why the sale was cancelled. 